\title{
Psycho-social attributes and quality of life: Overview and pilot study of commuters' travel behaviour
}

\author{
Taufik Tai ${ }^{1, *}$, Rohana $\mathrm{Ngah}^{2}$, and Muhammad Zaly $\mathrm{Shah}^{1}$ \\ ${ }^{1}$ Universiti Teknologi Malaysia, Department of Environmental Engineering, Johor, Malaysia \\ ${ }^{2}$ Universiti Teknologi MARA Depart. of Business and Management, Shah Alam, Malaysia
}

\begin{abstract}
As metropolitan cities have improved and upgraded their public transport infrastructure to encourage higher public transport ridership, the next challenges understand factors that influence the individuals' travel behaviour. Psycho-Social Attributes and Quality of Life are important elements to study the public transport ridership in metropolitan cities. This paper offers a short overview of the role of psycho-social and quality of life in understanding the travel behaviour of public transport in cities. The paper explores attributes such as social norms, personal norms, freedom, safety and comfort that have an impact on travel behaviour. Twenty-nine participants took part in the pilot study. Partial Least Square was used to analyze data. Results showed psycho-social attributes has strong direct relationship to travel behaviour while quality of life can be a good support for travel behaviour. Recommendation and suggestion are discussed.
\end{abstract}

\section{Introduction}

Many metropolitan cities have built a good public transit infrastructure, however, the ridership is still low [1]. Kuala Lumpur has gone into massive public transportation facelift for the last few years. According to Chuen et al [2], almost 83\% out of 7.23 million trips daily in Kuala Lumpur are made using private transport and single occupancy vehicles. Kuala Lumpur recorded only $20 \%$ of public transport compared to Singapore (67\%) and Hong Kong (87\%). A study by Nurdden, Rahmat and Ismail [3] found that age, gender, car ownership, travel time, travel cost, household size and income were significant factors in in influencing the individual's choice of transportation. Studies have shown that the accessibility distance to the rail transport system, transit time, and time spent using the service are the significant factors that will attract travelers, the accessible distance for the public bus service, as well as the bus network, buses transit time, and travelling time are the significant factors that will attract travelers however, as the income has improved significantly, psycho-social attributes will be useful in making the potential shift from private to public transport.

\footnotetext{
* Corresponding author: rohanangah@,salam.uitm.edu.my
} 
Travel behavior is to a large extent habitual [4]. Travel behavior can also explain by social expectations about behavior such as norms, values, beliefs, attitudes and finally lifestyle [5]. Attitude can be defined as positive or negative evaluations or beliefs held about something that in turn may affect one's behavior; attitudes are typically broken down into cognitive, affective, and behavior components [6]. In addition, traveler's attitude is becoming an important aspect in travel behavior research [7, 8]. According to attitude theory, attitude refers to the evaluation of a behavior, which disposes a person to behave in a certain way toward it [7]. Attitude is conceptualized as positive or negative evaluations or beliefs of something that affects one's behavior and can be broken down into cognitive, affective, and behavior components [6]. Social psychologists described attitudes as an element in the decision-making process [7] whereas transportation researchers described attitudes as part of the decision process [9]. Additionally, attitude along with intentions have a significant impact in understanding travel behavioral choices [10]. In the case of choosing public transportation, attitude was found to be more significant indicators than demographics and travel needs $[7,11,12]$. Traveler's attitude is becoming an important aspect of travel behavior research [7]. According to attitude theory, attitude refers to the evaluation of a behavior, which disposes a person to behave in a certain way toward it [13]. Attitude is conceptualized as positive or negative evaluations or beliefs of something that affects one's behavior and can be broken down into cognitive, affective, and behavior components [6].

Social factors include general factors at the level of human society concerned with social structure and social processes that impinge on the individual. Psychological factors include individual-level processes and meanings that influence mental states. Sometimes, these words are combined as "psychosocial." This is shorthand term for the combination of psychological and social, but it also implies that the effects of social processes are sometimes mediated through psychological understanding [14].

Lifestyle in urban cities can influence travel behavior [15]. Median monthly household income for Malaysian in 2014 increased to RM4,585 than RM3,626 in 2012 which is growing at the rate of 11.7 per cent annually [16]. Therefore, the lifestyle plays an important role in determining travel behavior in public transport in KL. In addition, various psycho-social factors appear to play a part in determining people's travel behaviors and how they perceive their travel choice $[17,18]$.

A smaller number of studies examined the influence of various psycho-social variables on travel behavior. Hiscock et al [19] studied the perceived psycho-social benefits of car usage and ownership. In particular, the authors studied the significance of the car as providing protection, autonomy and prestige compared with public transport where the respondents were car owners and non-car owners. The results found that there were some psycho-social benefits to car users. Car users felt that they gained protection, autonomy and prestige from their car and car ownership gave them 'street-cred'. Their car provided them with protection from 'undesirable' people, provided autonomy, convenience and greater access to a greater range of destinations than public transport. Socially desirable attributes such as competence, skill and 'masculinity' were also perceived to be derived from car ownership. People who didn't own cars were felt to be eccentric particularly those who chose to travel by bicycle [17].

Cullinane [20] found similar psycho-social perceptions amongst students attending five universities in Hong Kong. The findings are interesting in that car ownership was extremely low amongst the participants, less than $1 \%$ owned a car at the time of the study with the overall Hong Kong population having car ownership levels of 49 cars per 1000 population in 1999. Forty percent of participants felt that public transport was plentiful and low-cost in Hong Kong and suppressed their demand for a car. Few participants felt that they would own a car within the next ten years. However, latent demand was high particularly. 
A range of psycho-social variables has been identified as playing some part in influencing travel behavior many of which appear to be dominant in car-owning younger males. Those papers which identified these psycho-social variables tended to use subjective and qualitative measures and discussed the following [17]:

- Feelings of power

- Feelings of achieving 'street cred'

- Safety

- Protection from socially undesirable groups

- Feelings of prestige within peer group

- Identification with selected peer group

- Feelings of greater autonomy

- Perceptions of greater skill and competence through car ownership

- Perceptions of greater masculinity among male car-owners - interestingly no mention of greater femininity amongst female car-owners and users

- Non car-owners/users deemed to be 'eccentric' and hence undesirable

A study done by Verhoeven et al. [21] shows that psychosocial variables seemed to be more important than environmental variables where social norm, social modelling and social support are the most consistent psychosocial. Simons, De Bourdeaudhuij, Clarys,De Cocker, de Geus, Vandelanotte [21] adopt Attitude-Social influence-self- Efficacy (ASE) model to measure the travel behavior of working adults in Belgium focusing psycho-social attributes such as self-efficacy, social norm, modeling, social support, perceived benefits and perceived barriers. Meanwhile, Bourdeaudui, Teixeira, Cardon and Deforche [22] employs social variables, self-efficacy, perceived benefits and perceived barriers as psychosocial variables in their study on adults in Portugal and Belgium towards their perception of active public transport modes such as cycling and walking. Few other studies on psychosocial have been carried out to identify in western countries to measure their inclination towards usage of public transport.

Quality of Life (QoL) is perceived to be a reflection of how well individual needs and values are fulfilled in various fields of life as cited by Groot and Steg [23]. The Quality of Life (QoL) can be assessed from either individual or society level which further divided into objective and subjective indicators [23]. Time spent during congestion also affected drivers' well-being and quality of life as well as productivity where time is wasted during traffic congestion. The quality of life has been largely affected by urban transportation problems like traffic congestion. Studies on sustainable transport highlight the importance of QoL especially towards pro-environment and travel behavior [24].

Recently, factors like psycho-social, attitude, beliefs, personality and lifestylethat could influence travel behavior have been given more attention $[25,26]$. Psycho-social attributes or factors are seldom used in travel behavior study especially in public transport. Therefore, this study is attempts to explore commuters' travel behavior to increase public transit mode share in metropolitan cities through psycho-social variables and service quality. The study would provide clear issues in low public transit ridership in metropolitan cities. In addition, the authority would be able to identify factors of psycho-social and service quality that influence public transport usage thus would be able to encourage higher public transit ridership. The aim of this pilot study was to demonstrate the impact of psycho-social attributes and quality of life on travel behavior. It is hoped this information will contribute to the next generation of travel behavior studies, and help elucidate the links between the travel behavior and travel demand management. 


\section{Discussion}

\subsection{Methodology}

The pilot study was carried out to find out the validity of questionnaire and to amend it for a bigger scale survey. A total of 29 participants took part in the pilot test. Table 1 presents the overall sample structure for this study.

Table 1. Respondent profile

\begin{tabular}{|l|l|c|c|}
\hline Demographic Traits & Frequency & \% \\
\hline \multirow{3}{*}{ Gender } & Male & 10 & 34.5 \\
\cline { 2 - 4 } & Female & 19 & 65.5 \\
\hline \multirow{4}{*}{ Age } & Single & 23 & 79.3 \\
\cline { 2 - 4 } & Married & 9 & 20.7 \\
\cline { 2 - 4 } & Below 20 & 2 & 6.9 \\
\cline { 2 - 4 } & $21-30$ & 23 & 79.3 \\
\cline { 2 - 4 } & $31-40$ & 3 & 10.3 \\
\cline { 2 - 4 } & $41-50$ & 1 & 3.4 \\
\hline \multirow{5}{*}{ Education } & High School & 2 & 6.9 \\
\cline { 2 - 4 } & Diploma & 23 & 79.3 \\
\cline { 2 - 4 } & Degree & 3 & 10.3 \\
\cline { 2 - 4 } & Post-graduate & 1 & 3.4 \\
\hline & Unemployed & 1 & 3.4 \\
\cline { 2 - 4 } & Housewife & 11 & 3.4 \\
\cline { 2 - 4 } & Student & 11 & 37.9 \\
\cline { 2 - 4 } & Public Sector Employee & 4 & 3.4 \\
\cline { 2 - 4 } & Private Sector Employee & & 13.8 \\
\cline { 2 - 4 } & Others & 1 & \\
\hline
\end{tabular}

Based on gender, female constituted $65.5 \%$ while male represented $34.5 \%$ of the sample population. Most of the respondents were from the age group of $21-30$ years old. The majority of respondents have a college diploma (79.3\%). Most of the respondents are students and private sector employees.

\subsection{Constructs development}

The psycho social attributes (PSA) comprises of personal norm and social status. Quality of life (QoL) comprises of safety and comfort. PSA measurement was adopted from Moktarian et al [27], QoL from Steg and Giifford, de Groot [23] and travel behaviour was from Javid et al. [28]. Items statements in the variables sections are measured as subjective estimates using a five-point Likert scale (with $1=$ strongly disagree and $5=$ strongly agree).

\subsection{Data analysis}

Partial Least Squares (PLS) analysis technique using the SmartPLS 3.0 software [29] was employed to analyze the research model. Following the recommended two-stage analytical procedures by Anderson and Gerbing (1988), we tested the measurement model (validity and reliability of the measures) followed by an examination of the structural model (testing the hypothesized relationships) $[29,30]$. To test the significance of the path coefficients and the loadings, a bootstrapping method was used [29]. 


\subsection{Measurement model}

The measurement model is assessedby two types of validity which are convergent validity and discriminant validity. Convergent validity of the measurement model is usually ascertained by examining the loadings average variance extracted (AVE) and also the composite reliability [30]. The loadings were all higher than 0.7 , the composite reliabilities were all higher than 0.7 and the AVE values were also higher than 0.5 as suggested by Hair et al. [29] as shown in Table 2.

Table 2. Measurement model

\begin{tabular}{|c|c|c|c|c|c|}
\hline $\begin{array}{c}\text { 1st Order } \\
\text { Constructs }\end{array}$ & $\begin{array}{l}\text { 2nd Order } \\
\text { Constructs }\end{array}$ & Item & Loadings & $\mathrm{CR}$ & AVE \\
\hline \multirow{4}{*}{$\begin{array}{l}\text { Personal } \\
\text { Norms }\end{array}$} & & PN5 & 0.805 & \multirow[t]{4}{*}{0.912} & \multirow[t]{4}{*}{0.722} \\
\hline & & PN6 & 0.825 & & \\
\hline & & PN7 & 0.881 & & \\
\hline & & PN8 & 0.884 & & \\
\hline \multirow{3}{*}{$\begin{array}{l}\text { Social } \\
\text { Status }\end{array}$} & & SS1 & 0.783 & \multirow[t]{3}{*}{0.861} & \multirow[t]{3}{*}{0.755} \\
\hline & & SS2 & 0.877 & & \\
\hline & & SS3 & 0.802 & & \\
\hline & \multirow{2}{*}{$\begin{array}{l}\text { Psycho-Social } \\
\text { Attributes }\end{array}$} & Personal Norms & & \multirow[t]{2}{*}{0.873} & \multirow[t]{2}{*}{0.501} \\
\hline & & Social Status & & & \\
\hline \multirow{2}{*}{ Safety } & & SAF1 & 0.875 & \multirow[t]{9}{*}{0.861} & \multirow[t]{9}{*}{0.755} \\
\hline & & SAF2 & 0.863 & & \\
\hline \multirow[t]{9}{*}{ Comfort } & & $\mathrm{C} 2$ & 0.757 & & \\
\hline & & $\mathrm{C} 3$ & 0.832 & & \\
\hline & & $\mathrm{C} 7$ & 0.775 & & \\
\hline & & $\mathrm{C} 8$ & 0.790 & & \\
\hline & & C9 & 0.778 & & \\
\hline & & $\mathrm{C} 13$ & 0.740 & & \\
\hline & & $\mathrm{C} 14$ & 0.786 & & \\
\hline & \multirow[t]{2}{*}{ Quality of Life } & Safety & & \multirow[t]{2}{*}{0.899} & \multirow[t]{2}{*}{0.506} \\
\hline & & Comfort & & & \\
\hline \multirow{4}{*}{$\begin{array}{c}\text { Travel } \\
\text { Behavior }\end{array}$} & & TB1 & 0.714 & \multirow{4}{*}{0.857} & \multirow[t]{4}{*}{0.547} \\
\hline & & TB2 & 0.724 & & \\
\hline & & TB3 & 0.777 & & \\
\hline & & TB7 & 0.807 & & \\
\hline
\end{tabular}

Table 3 verified the interrelation of three latent constructs. Discriminant validity of the measures (the degree to which items differentiate among constructs or measure distinct concepts) was examined by following the Fornell and Larcker [31] criterion of comparing the correlations between constructs and the square root of the AVE for that construct as presented in Table 3, where the square root of the AVE (in diagonals) were greater than the correlation values indicating the measures were discriminant. In sum, both convergent and discriminant validity of the measures in this study were established.

Table 3. Discrimant analysis

\begin{tabular}{llllll}
\hline Constructs & Mean & S.D. & PSA & QoL & TB \\
\hline PSA & 3.40 & 0.466 & $\mathbf{0 . 7 0 7}$ & & \\
QoL & 3.03 & 0.491 & $0.742^{*}$ & $\mathbf{0 . 7 1 1}$ & \\
TB & 3.39 & 0.475 & $0.686^{* *}$ & 0.564 & $\mathbf{0 . 7 4 0}$ \\
\hline
\end{tabular}




\subsection{Structural model}

Structural equationmodeling is used to test the causal relationships among psycho-social, quality of life and travel behavior. In PLS, the path coefficients (t-values) and $R$-square are used to measure the strengths of latent variables. As shown in Figure 1, the model's predictive explanatory power for travel behavior refers to $R$-square to explain how much of the variance in the dependent variable can be explained by the independent variable. Psycho-social attributes explain $55 \%$ of quality of life while $61 \%$ of travel behavior can be explained by psycho-social attributes and quality of life. In this model as shown in Table 5, Psycho-Social has direct $(0.121)$ and indirect impact (0.054) on Travel behavior with total effect of 0.175 . This shows that Psycho-Social positively influences travel behavior while quality of life can additionally strengthen travel behavior.

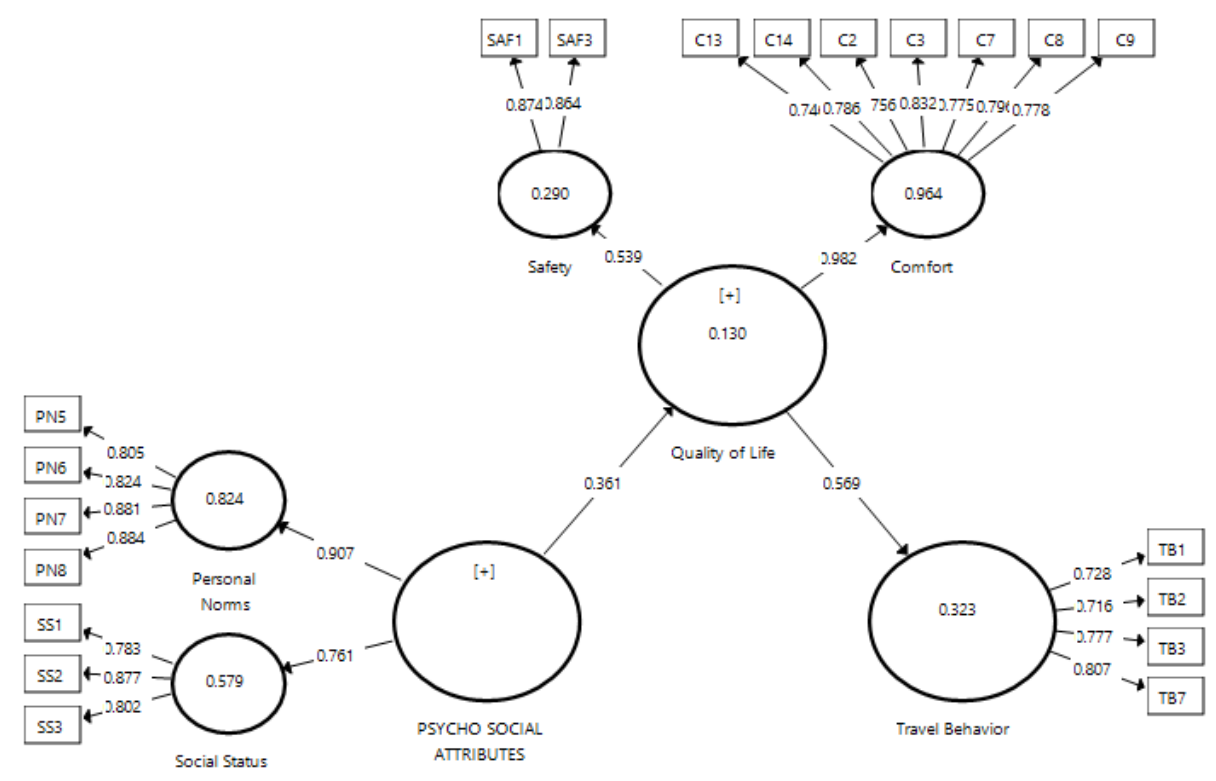

Fig. 1. Structural model

Table 4. Direct, indirect and total effects

\begin{tabular}{|l|c|c|c|}
\hline & Direct effect & Indirect Effect & Total effects \\
\hline Psyc-TB & 0.121 & 0.054 & 0.175 \\
\hline Psyc-QoL & 0.741 & & 0.741 \\
\hline QoL-TB Travel Behavior & 0.687 & & 0.687 \\
\hline
\end{tabular}

\section{Conclusion}

This paper has represented structural equation model of travel behavior that emphasize on psycho-social and quality of life on travel behavior. This study used pilot test to explore the relationship of latent constructs. The results demonstrate that psycho-social has direct and positive relationship to travel behavior while quality of life can be supporting elements to the relationship. This result is similar to study by Etminani-Ghasrodashti and Ardeshiri [5] where they found the strong relationship between psycho-social and travel behavior. 
Psycho-social attributes are the important elements for the metropolitan cities' residents where social norms and social status play strong role in influence individual's behavior especially in choosing their daily mobility pattern. In addition, quality of life is also another keyelement that should be included in a study of travel behavior as the awareness of environmental issues has been widespread. Understanding these two elements would help the relevant authorities to plan their strategies especially in travel demand management in increasing public transport ridership to $48 \%$ by 2030 in line with Transformation Plan of Greater Kuala Lumpur under $11^{\text {th }}$ Malaysian Plan. This study is not without limitation. First of all, the data was small as this is meant for pilot test. Thus, some of the empirical results were not encouraging. Secondly, most of the participants are students who might not have good exposure in public transport. However, this is a good preliminary study as students are the second largest public transport commuters. For future research, it is suggested that bigger sample to be collected to have more robust analysis and results. Beside, other elements such as service quality and trip chain attributes are less explored in travel behavior.

\section{References}

1. Choi, CC,and Loh, N., Transport Policies and Patterns: A comparison of five Asian Cities. Journeys .(2013).

2. Chuen, OC, Karim, MR, Yusoff, S, 2014, Mode Choice between Private and Public Transport in Klang Valley, Malaysia, The Scientific World Journal, Article ID 394587, http://dx.doi.org/10.1155/2014/394587. (2014).

3. Nurdden, A., Rahmat, R. A. O. K., and Ismail, A., Effect of transportation policies on modal shift from private car to public transport in Malaysia, Journal of Applied Sciences, 7(7), 1013-1018. (2007).

4. Verplanken, B., Aarts, H., van Knippenberg, A., and van Knippenberg, C., Attitude versus general habit: Antecedents of travel mode choice. Journal of Applied Social Psychology, 24,285-300. (1994).

5. Etminani-Ghasrodashti, R. and Ardeshiri, M., Modeling travel behavior by the structural relationships between lifestyle, built environment and non-working trips. Transportation Research Part A 78, 506-51. (2015).

6. Nairne, J.S., Psychology: The Adaptive Mind (3rd ed), Thomson Learning Inc. London. (2003).

7. Parkany,E., Gallagher, R., Viveiros, P. (20005). Are Attitudes Important in Travel Choices? Transportation Research Board Annual Meeting. (2005)

8. Thorpe, N., Hills, P., and Jaensirisa, S., Public attitudes to TDM measures: a comparative study. Transport Policy. 7, 243-257. (2000).

9. Sunkanapalli, S., Pendyala, R. and Kuppam, A. Dynamic Analysis of Traveler Attitudes and Perceptions Using Panel Data. In Transportation Research Record: Journal of the Transportation Research Board, 1718, -1, 2000, 52-60. (2000).

10. Outwater, M., S. Castleberry, Y. Shiftan, M. Ben Akiva, Y. S. Zhou and A. Kuppam, Use of Structural Equation Modeling for an Attitudinal Market Segmentation Approach to Mode Choice and Ridership Forecasting. Paper presented at the 10th International Conference on Travel Behaviour Research, Lucerne. (2003).

11. Garling, T., Eek, D., Loukopoulos, P., Fujii, S., Johansson-Stenman, O., Kitamura, R., Pendyala and Vilhelmson, B., A conceptual analysis of the impact of travel demand management on private car use. Transport Policy, 9, 59-70. (2002).

12. Fujii, S. and Garling, T., Application of Attitude Theory for Improved Predictive Accuracy of Stated Preference Methods in Travel Demand Analysis. Transportation Research Part A, 37(4), 389-402. (2003). 
13. Ajzen, I. and Fishbein, M., Understanding attitudes and predicting social behavior. Prentice-Hall,Inc., New Jersey.(1980).

14. Stansfeld, S., and Rasul, F. , Psychosocial factors, depression and illness. In A. Steptoe (Ed.), Depression and physical illness (pp. 19-52). Cambridge: Cambridge University Press. (2007)

15. Krizek, K. J., Household Lifestyles and Their Relationship to Land-Use and Transportation Planning. Minneapolis: Humphrey Institute of Public Affairs. http://www.cura.umn.edu/sites/cura.advantagelabs.com/files/publications/35-4Krizek.pdf. (2005).

16. Department of Statistic, https://www.dosm.gov.my/v1/. (2014).

17. Curtis,C., and Perkins, T., Travel Behaviour: A review of recent literature. Impacts of Transit Led Development In A New Rail Corridor Working Paper No. 3. Urbanet Department of Urban and Regional Planning Curtin University. (2006).

18. Lyons, G., Farag, S. and Haddad, H, The substitution of communications for travel? In: Ison, S. and Rye, T., eds., The Implementation and Effectiveness of Transport Demand Management Measures: An International Perspective. Ashgate, 211-232. ISBN 9780754649533 Available from: http://eprints.uwe.ac.uk/8692. (2008)

19. Hiscock, S. Macintyre, A. Kearns, and A. Ellaway, Means of transport and ontological security: do cars provide psycho-social benefits to their users? Transportation Research Part D, 7 (2), 119-135. (2002)

20. Cullinane, S, The relationship between car ownership and public transport provision: a case study of Hong Kong, Transport Policy, 9(1), 29-39. (2002).

21. Verhoeven H, Simons D, Van Dyck D, Van Cauwenberg J, Clarys P, and de Bourdeaudhuij I., Psychosocial and Environmental Correlates of Walking, Cycling, Public Transport and Passive Transport to Various Destinations in Flemish Older Adolescents. PLoS ONE 11(1): e0147128. https://doi.org/10.1371/journal.pone.0147128. (2016)

22. De Bourdeaudhuij, I, Teixeira, PJ, Cardon, G, and Deforche, B, Environmental and psychosocial correlates of physical activity in Portuguese and Belgian adults, Public Health Nutrition: 8(7), 886-895, DOI: 10.1079/PHN2005735. (2005).

23. Groot, JIM and Steg, L., The role of value orientations in evaluating quality of life consequences of a transport pricing policy, Transportation Research Part D 11 (2006) 160-165. (2016).

24. Steg, L., and Gifford, R., Building Blocks for Sustainable Transport, Volume 1, Emerald Group Publishing Limited. DOI:10.1016/B978-0-08044-709-4.00011-2. (2008).

25. Ory, David.,Mokhtarian, P., Modeling the structural relationships among shortdistance travel amounts, perceptions, affections, and desires. Transp. Res. Part A 43, 26-43. (2009).

26. Van Acker, V., Mokhtarian, P., Witlox, F., Car availability explained by the structural relationships between lifestyles, residential location, and underlying residential and travel attitudes. Transp. Policy 35, 88-99. (2014)

27. Mokhtarian PL, I Salomon and ME Singer,, What moves us? an interdisciplinary exploration of reasons for traveling. Transport Reviews. (2015).

28. Javid, M.A., Okamura, T. Nakamura, F., Tanaka, S., and Wang, R., Factors Influencing the Acceptability of Travel Demand Management (TDM) Measures in Lahore: Application of Behavioral Theories. Proceedings of the Eastern Asia Society for Transportation Studies, 9. (2013).

29. Hair, J. F., Hult, G. T.M., Ringle, C. M., \&Sarstedt,M., A primeron partial least squares structural equation modeling (PLS-SEM).Los Angeles: Sage Publication. (2014). 
30. Gholami, R., Sulaiman, A. B., Ramayah, T., and Molla, A., SeniorManagers' Perception on Green Information Systems (IS) Adoptionand Environmental Performance: Results from a Field Survey.Information Management, 50(7), 431-438. (2013).

31. Fornell, C., andLarcker, D. F., Evaluating Structural EquationModels with Unobservable Variables and Measurement Error.Journal of Marketing Research, 18(1), 39-50. (1981). 